\title{
Review
}

\section{The role of T-cells in the pathogenesis of Type 1 diabetes: From cause to cure}

\author{
Bart O. Roep \\ Dept. Immunohaematology and Blood Transfusion, E3-Q, Leiden University Medical Center, Leiden, The Netherlands
}

\begin{abstract}
Type 1 diabetes mellitus results from a T-cell mediated autoimmune destruction of the pancreatic beta cells in genetically predisposed individuals. The knowledge of the immunopathogenesis has increased enormously in the last two decades. The contribution of T-cells in the pathogenesis is beyond doubt. Therapies directed against T-cells have been shown to halt the disease process and prevent recurrent beta-cell destruction after islet transplantation. Less is known about the nature and function of these T-cells, the cause of the loss of tolerance to islet autoantigens, why the immune system apparently fails to suppress autoreactivity, and whether (or which) autoantigen(s) are critically involved in the initiation or progression of the disease. The contribution of dendritic cells in directing the immune response is clear, while the contribution of $\mathrm{B}$-cells and autoantibodies is subject to reconsideration. Autoreactive T-cells have proven to be valuable
\end{abstract}

tools to study pathogenic or diabetes-related processes. Measuring T-cell autoreactivity has also provided critical information to determine the fate of islet allografts transplanted to Type 1 diabetic patients. Cellular autoimmunity is a difficult study subject, but it has been a worthwhile quest to unravel the role of T-cells in the pathogenesis of Type 1 diabetes. The challenge for the future is to determine which factors contribute to the loss of tolerance to beta-cell antigens, and to define what measures T-cells can provide to suppress autoreactivity, since it is becoming increasingly evident that T-cells provide a two-edged sword: some T-cells could be pathogenic, but others can regulate the disease process and thus form new targets for immunointervention. [Diabetologia (2003) 46:305-321]

Keywords Autoimmune disease, immunotherapy, islet transplantation, HLA, T lymphocyte, immune regulation, suppressor T-cell, autoreactive T-cell, islet autoantigen.
Received: 28 January 2003 / Revised: 6 March 2003

Published online: 22 March 2003

C) Springer-Verlag 2003

Corresponding author: Dr. Bart O. Roep, Dept. Immunohaematology and Blood Transfusion, E3-Q, Leiden University Medical Center, P.O. Box 9600, 2300 RC Leiden, The Netherlands E-mail: boroep@1umc.nl

Abbreviations: NOD, non-obese diabetic; ICA69, islet cell autoantigen 69; CTLA4, cytotxic T-lymphocyte-associated antigen 4; NKT, natural killer T-lymphocyte; IDS, Immunology of Diabetes Society; ICAM, intercellular adhesion molecule; APC, antigen-presenting cell; hCMV, human cytomegalovirus; SMS, stiff-man syndrome; DC, dendritic cell; ELISPOT, enzyme-linked immunosorbant spot assay; APL, altered peptide ligand; TCR, T cell receptor; ALG, anti-lymphocyte globulin; ATG, anti-thymocyte globulin.

\section{Role of T-cells in beta-cell destruction}

Type 1 diabetes mellitus is a T-cell dependent immune-mediated disease in which the insulin-producing pancreatic beta cells are destroyed [1]. Evidence for this idea first came from histology of pancreata of newly-diagnosed Type 1 diabetic patients [2]. T-cells are present in the inflammatory lesion (insulitis) [3] (Fig. 1 and 2; Table 1). Insulitis is only present in islets with beta cells, which implies that the islet infiltration is a beta-cell driven process. Immunosuppressive drugs, including those specifically directed against T-cells, have been shown to delay the disease progress [4]. This clinical 'benefit' was not accompanied by changes in autoantibody levels [5]. A recent 
pilot study testing non-activating humanised monoclonal antibody directed against CD3 suggests preservation of beta cells even at clinical manifestation of the disease [6]. Recurrent selective beta-cell destruction in a pancreas segment transplanted between identical twins from a non-diabetic twin to a diabetic twin provided strong evidence of the immunological memory of islet-specific T-cells [7]. Again, this recurrent autoimmune destruction was not accompanied by rises in autoantibody titres. More recent studies showed the possibility of 'adoptive transfer' of diabetes following transplantation with bone marrow that was not depleted for T-cells from a diabetic donor to a non-diabetic immunocompromised recipient relative [8]. Interestingly, this case report has since been confirmed by several other cases all sharing the notion that the bone marrow graft still contained T-cells, while many other successful transplantations with T-cell depleted bonemarrow of diabetic donors have been achieved. Additional proof of T-cell autoimmunity in Type 1 diabetes stems from detection of circulating autoreactive T-cells at clinical onset of disease that are associated with the presence of insulitis (Fig. 3) [9], but a problem is that such reactivity is usually not disease-specific (see below). Nonetheless, longitudinal studies on circulating auto- and alloreactive T-cells in Type $1 \mathrm{di}$ abetic patients transplanted with pancreatic islet allografts provided a strong association between graft function and T-cell auto- and/or alloimmunity (Fig. 4) [10].

Several candidate autoantigens have been defined in the course of the last two decades. These antigens have in common that they are not beta cell specific, nor is autoimmunity against these antigens Type 1 diabetes specific [11]. The detection of islet-reactive autoantibodies provided the first strong evidence in favour of an autoimmune-mediated pathogenesis of Type 1 diabetes [12]. These autoantibodies provided the tools to identify the candidate targets on the beta cells. It took more than a decade to identify some of these target structures in the islets $[13,14,15]$. With the identification of candidate islet autoantigens recognized by autoantibodies, the search for disease-associated T-cells was boosted [16]. However, it remains to be seen whether the antibody targets are the correct choice to study disease-associated T-cell reactivity. It is already clear that other potential islet autoantigens serve as a target for autoreactive T-cells in diabetes that are not (yet) accompanied by humoral autoreactivity $[9,17,18]$.

Although it is conceivable that determinants that distinguish beta cells from other cell types, including the other endocrine cells in the pancreatic islets of Langerhans, insulin and its precursor proteins seem to be the only specific antigens specifically produced by beta cells that serve as a target, be it not exclusively in patients with Type 1 diabetes. Yet, insulin is circulating throughout the body, including the thymus, where the immune system is educated to ignore self-proteins by negative selection of self-reactive T-cells. Therefore, with its wide distribution, insulin does not fulfil the criteria for autoreactivity under the hypothesis that peripheral non-thymic expression of self-proteins not involved in negative thymic selection of T-cells could lead to potential lack of tolerance against such candidates. As a matter of fact, proinsulin is expressed in the thymus, in genetically determined levels [19]. Nonetheless, insulin is the only autoantigen recognized by autoantibodies in NOD mice [20].

It is already clear that other potential islet autoantigens serve as targets for autoreactive T-cells in diabetes that are not accompanied by humoral autoreactivity $[9,17,18]$. Intriguingly, although the initial report contained some flaws, several additional reports describe pronounced differences and inverse correlations between $\mathrm{T}$ - and B-cell responses to beta-cell autoantigens including insulin, GAD65, GAD67 and ICA69 $[21,22]$. The contribution of autoantibodies to development of Type 1 diabetes remains to be determined. Although autoantibodies can contribute to (auto-)immune responses in many ways, such as complement activation, opsonisation, improved antigen uptake by professional antigen-presenting cells [23], a recent report on development of Type 1 diabetes in a patient with severe hereditary B-cell deficiency provides compelling evidence that neither B-cells nor autoantibodies are essential in the pathogenesis of Type 1 diabetes [24]. Importantly, this patient expressed HLADR3-DQ2 and -DR4-DQ8 that provide the strongest genetic predisposition to develop Type 1 diabetes [25]. Interestingly, the T-cell response to recall antigen in this study was not different from non-diabetic subjects, while T-cell autoreactivity was clearly present, and not different from other newly-diagnosed Type 1 diabetes patients [24]. The study serves as an illustration of the benefit of T-cell studies in unravelling the aetio-pathogenesis of autoimmune disease. Although this recent finding should not be interpreted as proof that autoantibodies are not relevant in the disease process, it is in line with earlier observations showing lack of efficacy of immunotherapy directed against the humoral immune response, such as plasmapheresis or intravenous immunoglobulin therapy [26].

Several studies indicate multiple abnormalities in leukocyte composition associated with Type 1 diabetes, including NKT cells, CD45R-subpopulations, dendritic cells and CD4 and CD8 T-cells [27, 28, 29, $30,31,32,33,34,35,36]$. The causes of these differences and the association with the disease process remain to be elucidated. A possible cause could be a defect in immunoregulation. 


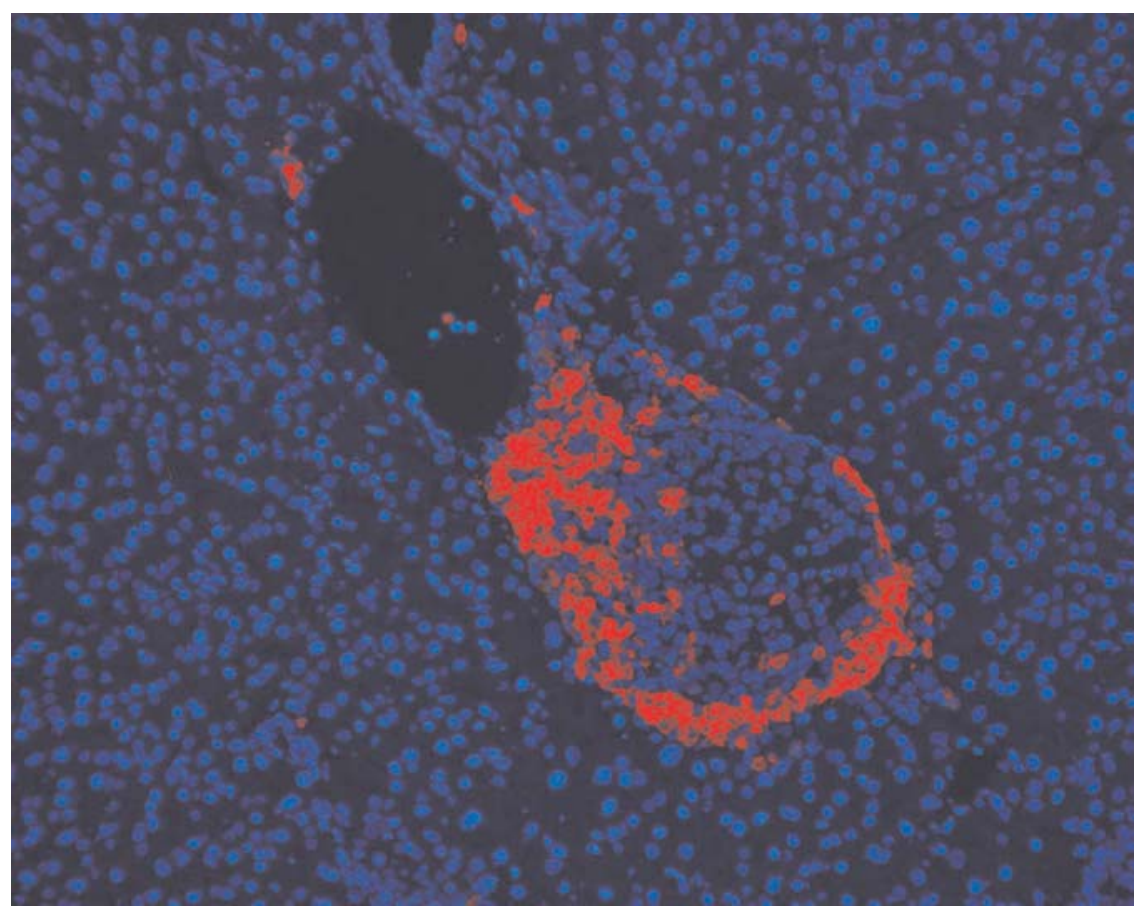

Fig. 1. Insulitis. Inflammation of the pancreatic islets with mononuclear cells including T-cells is the hallmark of Type 1 diabetes (courtesy A. van Halteren)

\section{Role of T-cells in protection from beta-cell destruction}

The immune response is naturally regulated by various mechanisms aimed at controlling hyperactivity and preventing self-destruction. It is therefore conceivable that any dysregulation in T-cell autoreactivity possibly leading to Type 1 diabetes is counteracted by suppressive immune responses (Fig. 2). This could be one of the explanations why T-cell autoreactivity is not synonymous with autoimmune disease. Several reports suggest a regulatory dysfunction in Type 1 diabetes [27, 36, 37]. Indeed, non-diabetic subjects have often been shown to contain circulating autoreactive T-cells $[18,38,39,40,41]$. A major challenge will be to distinguish pathogenic from 'benign' autoimmunity in this regard. However, the potential of a counteracting immune response could be associated with the difficulties associated with studies on autoreactive T-cells in human endocrine autoimmune diseases. In other immune-mediated diseases such as Crohn's disease and allograft rejection, particular T-cell subsets have been identified that have immunoregulatory function. Although a clear phenotype is not yet determined, these T-cell subsets share the production of IL-10 with or without interferon-gamma as feature $[42,43]$. Expression of CD4 and CD25 has been proposed as a marker for regulatory T-cells [44, 45, 46], but in humans, this phenotype describes in vivo active T-cells including the autoreactive T-cell subset, that also includes cells expressing activation markers such as HLA class II and CD134 [37]. CD4 and CD25 therefore do not qualify as a descriptor of suppressive T-cells, and additional markers are required that could include CTLA4. In vitro generation of suppressive T-cells has been a major challenge, but seems to be possible with help of for instance IL-10 [43, 47]. The only example of T-cells with suppressive function in Type 1 diabetes stems from an as yet ill-defined lymphocyte subset that expresses CD45RA. In apparently non-responsive patients, pronounced T-cell autoreactivity could be detected in isolated in vivo activated T-cells (expressing both CD45RA and CD45RO) that could be completely suppressed by CD45RA expressing lymphocytes [37]. This unique example illustrates the potential of suppressive T-cell subsets masking peripheral autoreactivity, and hence affect the possibility to detect T-cell autoreactivity.

\section{T-cell assay standardization}

As argued above, T-cell autoreactivity is not exclusive for any autoimmune disease. Consequently, efforts to determine disease-associated T-cell autoreactivity associated with Type 1 diabetes have been hampered by the false expectation that sensitive and specific technology exists that allows reproducible measures for disease activity (Table 2).

Appreciative of the above notion, international workshops on T-cell autoreactivity were organised under the auspices of the international Immunology of Diabetes Society (IDS) to standardise immunoassays to allow comparison between different studies $[39,48,49]$. The IDS has an excellent track record on 


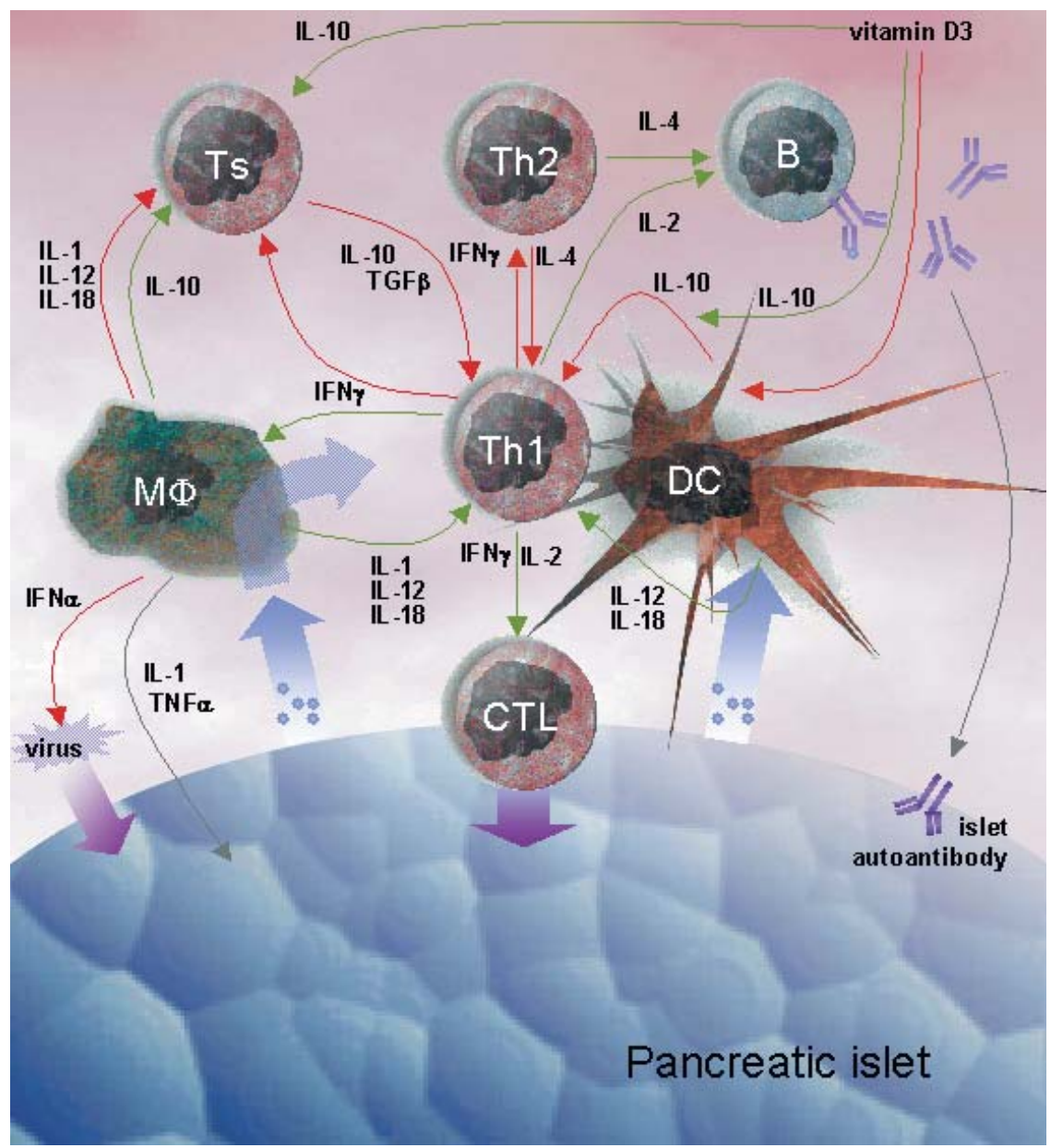

Fig. 2. Crosstalk between immune system and islets of Langerhans. Several components of the immune system interact with pancreatic islets. Beta-cell proteins [e.g., (pro-)insulin, IA-2, GAD65] become exposed to the immune system, for instance due to a viral insult on the islet or local stress, and are taken up, processed (blue arrows) and transported to pancreatic draining lymph nodes by professional antigen-presenting cells [macrophages $(M \varphi)$ or dendritic cells (DC)], where they can prime and stimulate autoreactive T-cells. The type of T-cells that results from this activation depends on the crosstalk between various components of the immune system. Proinflammatory T-cells (Th1) are promoted by release of IL-12, IL-18 and IL-1 by anti- gen presenting cells, while Th2 cells or suppressor T-cells become activated by IL-10, IFNg and IL- 4 produced by antigenpresenting cells and lymphocytes. Sometimes, cytokines are stimulatory (green arrows), sometimes they inhibit differentiation and activation (red arrows). The final outcome of this balance of autoimmunity and regulation determines the fate of the target beta cells. T-cells are involved in both arms of the balance between autoimmunity and immune regulation. Beta cells are subject to attacks from environment (e.g., virus, drugs), cytokines, cytotoxic T-cells (CTL) and antibodies, although the latter do not seem to cause beta-cell damage directly (purple). (P. Hanifi Moghaddam kindly provided digital assistance for this graph)

Table 1.

Support for a role of T-cells in the pathogenesis of Type 1 diabetes

Presence in inflammatory lesion (insulitis)

Delay of progress in disease with immunosuppressive drugs

Preservation of beta cells at clinical onset of disease after anti-CD3 monoclonal antibody therapy.

Recurrent selective beta-cell destruction in pancreas graft transplanted to diabetic monozygous twin.

'Adoptive transfer' of diabetes with bone marrow (not depleted for T-cells) from diabetic donor to non-diabetic recipient

Circulating autoreactive T-cells in Type 1 diabetes patients

Concordance between islet graft failure and increase in T-cell autoreactivity

Lack of benefit from plasmapheresis and intravenous immunoglobulin therapy

Development of autoimmune Type 1 diabetes in B-cell and antibody deficient patient with in tact T-cell immunity.

\section{Reference}

$[2,3,107,108,109,110]$

$[4,111,112,113]$

[6]

[7]

$[9,16,17,40,114,115,116,117]$

[10]

[26]

[24] 


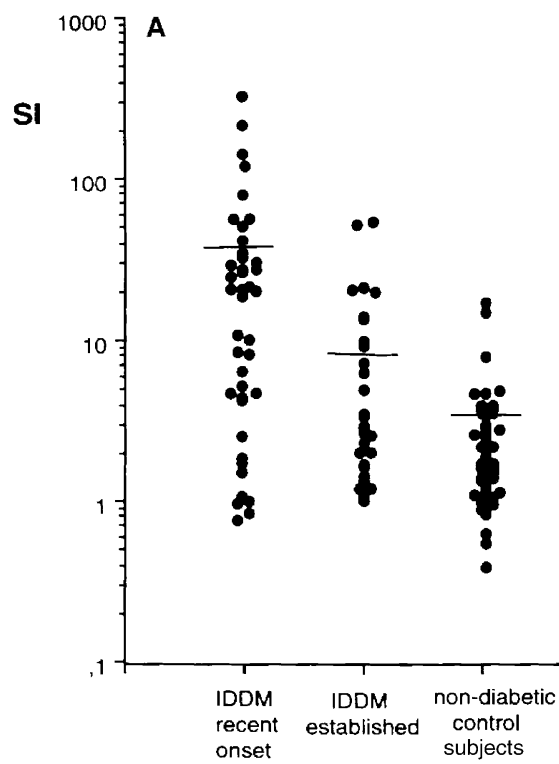

Fig. 3A, B. T-cell proliferation to insulin-secretory granules and recall antigen. (A) Children with newly diagnosed Type 1 diabetes have increased proliferative responses in peripheral blood mononuclear cells against insulin-secretory granule membrane preparations, as compared to non-diabetic children with unrelated chronic inflammations. Type 1 diabetic patients with the disease for 6 months or more (with presumably no in-

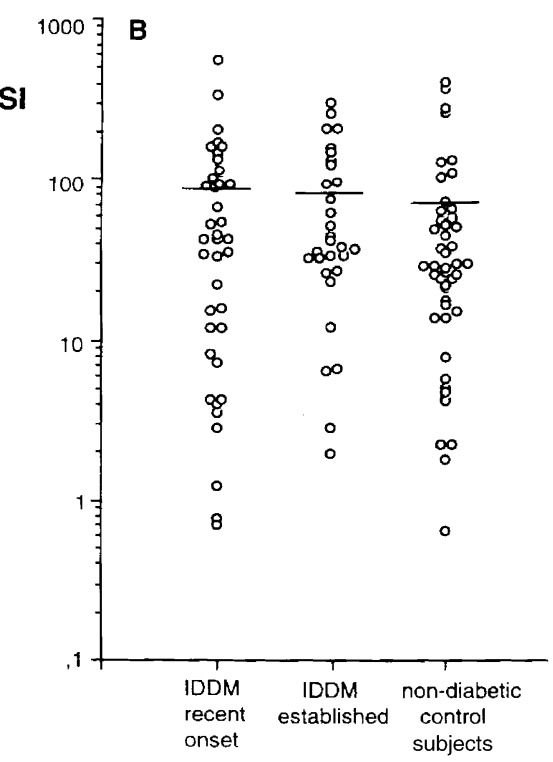

sulitis) still express increased autoimmunity, albeit less than patients at diagnosed. T-cell responses to the recall antigen tetanus toxoid (B) are not different between these three groups of subjects. (Copyright (C) 1995 American Diabetes Association. From Diabetes, Vol. 44, 1995;278-283. Reprinted with permission from the The American Diabetes Association)

Table 2.

Issues affecting progress in T-cell research in Type 1 diabetes

Lack of sensitive and reproducible detection assay

Quality of recombinant autoantigens; choice of target autoantigen or peptide epitope

Choice of control subjects

Discordance between experimental models and human disease

Inaccessibility to inflammatory lesion

Relevance of circulating autoreactive T-cells

Potential hyper-responsive immune status in recent onset patients

Low precursor frequencies of circulating autoreactive T-cells
Reference

$[39,48,49]$

$[11,39,48,49,65]$

$[17,30,38,39,63,118,119]$

[95]

$[120,121]$

$[18,39,52]$

$[121,122]$

Limited diagnostic value (in cross-sectional studies) due to prevalence of autoreactive T-cells in patients and controls.

Immunoregulation

Discordance between cellular and humoral autoimmunity

Lack of technologies to detect autoreactive T-cells

False expectations

Required expertise
[123]

$[21,124,125,126]$

$[39,48,49]$

$[48,49]$

[39] standardisation of assays for the detection of diabetesassociated autoantibodies [50]. Unfortunately, the experience gained in the latter efforts could not be translated easily to T-cell assay standardisation studies in humans. Disappointment that could have arisen from the slow progress achieved in the standardisation efforts could be attributable to unrealistic expectations, and lack of recognition of multiple and sometimes unique limitations associated with human T-cell assays [51]. The most obvious limitation is the inability (for ethical and practical reasons) to conduct experiments in vivo. Inaccessibility to the target organ severely hampers the in vitro studies, and limits our efforts to define surrogate markers of insulitis. Levels of autoreactive T-cells in circulation are much lower than those in inflammatory lesions. This contrasts the situation with autoantibodies. Unfortunately, the in vitro manipulation could introduce misleading artefacts that are associated with factors like the isolation procedure, antigen concentration, source of serum in culture medium, etc. In addition, unlike autoantibody molecules, T-cells cannot be frozen and thawed without affecting their functional capacities. In addition to these factors, simple enumeration of T-cells before 
and after antigen stimulation is, in many cases, not mathematically feasible because the responding cells are present in very small frequencies in peripheral blood (i.e., less than 1 in 100000 cells in the total cell population). Finally, the purity of the antigen preparations needed for detection of autoreactive Tcells has been proven to be a critical variable to allow or prevent accurate measurements of circulating autoreactive T-cells $[39,48]$.

Due to the lack of technologies to determine T-cell autoreactivity, the insufficient quality of antigen preparations, and the difficulty to define relevant immunogenic synthetic peptide epitopes of islet autoantigens, the progress has been slow. In addition, the need for appropriately selected control subjects for comparison with diabetic patients seems underestimated. However, appreciating the contribution of HLA polymorphism in T-cell repertoire selection, tolerance induction and antigen presentation, and the experience that autoimmunity becomes less pronounced with age, it is critical to choose HLA- and age-matched control subjects as a reference to determine disease association of a given T-cell response. In fact, non-diabetic siblings of Type 1 diabetic patients have frequently been shown to respond in a similar way to their Type 1 diabetic relatives than unrelated control subjects. Considering the possibility that clinical onset of Type 1 diabetes could be accompanied by a generalised hyperimmune response $[18,52]$, it should also be considered to include control subjects suffering from chronic inflammation not related to Type 1 diabetes [17]. The T-cell committee of the Immunology of Diabetes Society has recommended a sensitive and reproducible assay for the detection of autoreactive T-cells (Table 3) [17].

\section{Lessons from autoreactive T-cell clones: unravelling the pathogenesis}

Considering the above described limitations of autoreactive T-cell studies, it might come as a surprise that considerable progress has been made in the last decade in unravelling the pathogenesis of Type 1 diabetes, defining potential environmental triggers associated with the initiation of the disease process, defining targets from immunotherapy and monitoring immunological and clinical efficacy of immunotherapy thanks to such T-cell studies (Table 4, Fig. 2).

With autoreactive T-cell clones as a reagent or probe it has become feasible to study particular processes that could play a part in the pathogenesis of Type 1 diabetes. Firstly, autoreactive T-cell clones have been used to identify candidate islet autoantigens that had not previously been characterised by autoantibodies [53, 54]. Secondly, autoreactive T-cell clones isolated from newly diagnosed or pre-diabetic patients have been used to design and study potential immuno- therapeutic strategies in vitro, such as chimeric soluble ICAM-1 and -3 (important intercellular adhesion molecules required for costimulation of T-cells and extravasation) [55, 56], proteases [57], and altered peptide ligands of autoantigenic peptide epitopes [58]. These altered peptide ligands efficiently down-regulate in vitro activation of a $38 \mathrm{kD}$-specific Th1 clone induced by either its peptide epitope or by native beta cell autoantigen. Self-peptide reactive T-cell proliferation could be inhibited only when APL and the selfpeptide were present on the same APC. Unrelated peptides with equal HLA-DR binding affinity were not effective, excluding simple MHC competition as the mechanism for T-cell modulation. APL triggered up-regulation of CD69 and CD25 expression, but not T-cell proliferation, TCR down-modulation or T-cell anergy. Thus, the APL inhibited beta cell autoantigeninduced activation of an autoreactive T-cell clone derived from a Type 1 diabetes patient by acting as partial TCR agonists that inhibit TCR down-modulation

In case of protease therapy, an approach that is used clinically to treat cytokine-mediated oedema in sport injury, it could be demonstrated that various cytokines alone, or in combination, changed cell surface expression of adhesion, co-stimulatory and homing molecules on both antigen-presenting cells and T-cells. Cytokine analyses showed a selective inhibition of proinflammatory (Th-1) but not Th-2 cytokine production. Autoreactive T-cell proliferation was inhibited at pharmacological serum concentrations, whereas non-specific proliferation to phytohaemagglutinin was not affected at these concentrations. Preincubation experiments on T-cells and antigen-presenting cells separately showed that this effect was mediated by APCs, but not T- cells [57].

Other T-cell studies that contributed to our understanding of the pathogenesis of Type 1 diabetes include the immunomodulatory function of glycolipids in the islet microenvironment [59] and the previously described determination that, in contrast to T-cells, autoantibodies are not strictly required in the disease process in Type 1 diabetes [24].

A recent study used an autoreactive T-cell clone against GAD65 that was directed against GAD65 to study possible involvement of islet endothelium in processing and presentation of beta-cell autoantigen [60]. Indeed, endothelium that was preactivated by cytokines expressed HLA class II as well as costimulatory molecules, and was able to efficiently process and present GAD65 to autoreactive T-cells. Remarkably, activated endothelium that presented autoantigenic epitopes caused autoreactive T-cells to selectively transmigrate through the endothelial cell layer, and provides an in vitro model resembling extravasation of T-cells into the intra-islet milieu. This study provides evidence for a role of islet endothelium in both antigen processing and presentation, 
Table 3. Protocol for primary proliferation assay for autoreactive T-cells

\begin{tabular}{ll}
\hline Step & Details \\
\hline Draw blood & B\&D vacutainer system; Na or Li \\
Ship sample & Room temperature
\end{tabular}

Ficoll gradient

Remove interphase and wash interphase twice with HBSS and resuspend in Iscoce's Modified Dulbecco's Medium (IMDM) supplemented with human pool serum $(20 \%)$

Count mononuclear cells;

dilute cells to $1.5 \mathrm{X} 10^{6} / \mathrm{ml}$

IMDM/20\%HS.

Add antigen preps to round-bottom 96-well plate.

Add cells to plate

Incubate

Add $0.5-1.0 \mu \mathrm{Ci}{ }^{3} \mathrm{H}$-thymidine; incubate overnight.

Harvest DNA

Count cpm
Dilute up to $20 \mathrm{ml}$ of blood to $35 \mathrm{ml}$ in Hanks' Balanced Salt Solution (HBSS) in $50 \mathrm{ml}$ tube.

Put $10 \mathrm{ml}$-pipet filled to top $(\approx 14 \mathrm{ml})$ with Ficoll (density $1077 \mathrm{~g} / \mathrm{ml}$ ) under blood solution and release Ficoll passively under blood.

Spin for 20' at RT, $350 \mathrm{~g}$, no brake. $280 \mathrm{~g}$, RT, brake

$2 \mathrm{ml} \mathrm{IMDM} / 20 \% \mathrm{HS}$ per $10 \mathrm{ml}$ of heparinized blood

dilute cells 1:10 in Türk solution, which lyses erythrocytes and stains nuclei.

Concentrate Ag prep 2X in $100 \mu \mathrm{l}$ per well;

Ag medium: IMDM (no serum).

Test dose response (final concentration of most recombinant antigens: 5-10 $\mu \mathrm{g} / \mathrm{ml}$; peptides: 2-10 $\mu \mathrm{g} / \mathrm{ml}$ ) Use tissue-coated plates. $100 \mu \mathrm{l} \approx 150000$ cells/well

5 days, $37^{\circ} \mathrm{C}, 5 \% \mathrm{CO}_{2}, 90 \%$ humidity.

in $50 \mu \mathrm{l}$ RPMI 1640.

semi-dry glass fibre filters are recommended for optimal signal/noise ratio
Comments

Shake tubes gently to avoid clotting

Heparin does not work at $4^{\circ} \mathrm{C}$; make sure that the assay is carried out within $24 \mathrm{~h}$ after blood draw.

Ship blood in heparin; do not ship ficoll interphase

Make sure that all solutions

(Ficoll, media) are at RT.

IMDM is not appropriate for cryopreservation (use RPMI 1640 w/o Hepes).

Check each individual serum before pooling in mixed lymphocyte culture to ensure that sera qualify for proliferation assays. Also check pooled serum in MLR. HS is heterogeneous; reserve single pool for longitudinal and comparative studies.

Counting of thawed cells is recommended in eosin, to exclude dead/dying (i.e., red) cells.

PS: cryopreservation affects monocytes, T-cell blasts and autoreactivity, and removes IL-10 from system.

Round-bottom plates are required for primary assays to ensure optimal cell-cell contact, while flat-bottom plates are recommended after initial in vitro stimulation.

Adding Ag to wells first prevents spillover of cells (round-bottom!), and ensures that cells are kept under unfavorable conditions $(\mathrm{pH}$, humidity, temperature) to minimum of time.

Add cells quickly with repetition pipet and move plate immediately to incubator.

Do not pile up more than five plates, to ensure gas exchange for medium buffering.

Ensure water is completely removed to prevent quenching of scintillation signal.

\section{Table 4.}

Perspectives for T-cell studies in Type 1 diabetes

Unravelling of immuno-pathogenesis

Definition for targets for immunotherapy

Monitoring of immunological and clinical efficacy of immunointervention trials

Identification of triggers initiating autoimmune disease process

Development of appropriate immunotherapy

Guidance of immune regulatory therapy

New technologies (ELISPOT, HLA tetramers)
Reference

$[9,23,24,59,77,80,83]$

[6]

$[10,122]$

$[9,80]$

[57]

$[10,127]$

$[122,128]$ 
and migration of autoreactive T-cells to insulitic lesions.

Autoreactive T-cell clones also proved useful to test the popular hypothesis that molecular mimicry, i.e. cross-reactivity between hoologous components of environmental and autologous proteins, contributes to the initiation of the autoimmune process. This study therefore led to the identification of an environmental trigger that could lead to a break of immunological tolerance to self-protein.

\section{Genetic and environmental factors associated with T-cell autoreactivity}

An association between $H L A$ and Type 1 diabetes is generally accepted [61]. Since HLA is important in the development of the T-cell repertoire in the thymus, as well as a restriction element in the adaptive immune response to (auto-)antigenic determinants, it is tempting to speculate that the protein products of $H L A$ genes, rather than genes in the $M H C$ region of chromosome 6 linked to $H L A$, are associated with the disease. We therefore analyzed the HLA-DR binding affinities of synthetic peptides covering the entire sequences of GAD65, islet cell antigen 69 (ICA69), and (pro)insulin, which are candidate antigens in the autoimmune process of T-cell-mediated destruction of the pancreatic beta cells [62]. Subsequently, peptide HLA-DR binding was correlated to peptide antigenicity by comparing known T-cell epitopes with their HLA-binding affinities defined in this study. The results show the following. (i) (Pro)insulin peptides have a strong binding affinity for HLA-DR2, which is associated with negative genetic predisposition to Type 1 diabetes, whereas poor binding was observed for HLA-DR molecules neutrally or positively associated with Type 1 diabetes. This suggests that the absence of insulin-reactive T-cells in DR2+ individuals could be explained by negative selection on highaffinity DR2 binding insulin peptides. (ii) Most autoantigenic peptides have promiscuous HLA-DR binding patterns. This promiscuity in itself is not sufficient to explain the genetic association of $H L A-D R$ with development of Type 1 diabetes. (iii) HLA-DR3 binding of autoantigenic GAD65 peptides is relatively weak compared with that of other known T-cell epitopes. (iv) All peptide epitopes recognized by HLA-DRrestricted T-cells from either Type 1 diabetes patients or GAD65-immunized HLA-DR transgenic mice bind with high affinity to their HLA-DR restriction molecule. In contrast, T-cell epitopes recognized by nondiabetic controls bind DR molecules with weak or undetectable affinity. These results thus indicate a strong correlation between antigenicity and HLA-DR binding affinity of GAD65 peptides in Type 1 diabetes. Furthermore, negative thymic selection of insulin peptides in low-risk (HLA-DR2 expressing) subjects could explain the lack of autoreactivity to insulin in such individuals. Specific responses to islet autoantigens that were associated with particular predisposing HLA polymorphisms have not been described yet. Nonetheless, it is clear that matching of non-diabetic controls with Type 1 diabetic patients for HLA is critically important [63]. A surprising observation in this regard is that in one study where patients and control subjects were carefully matched for HLA, a negative correlation was observed between proliferative responses to GAD65 and presence of HLA-DR3/4 [38]. In the case of islet autoantigen ICA69, we found that T-cell responsiveness was significantly higher in recent onset Type 1 diabetes patients, compared to Type 1 diabetes patients with post-disease onset, non-diabetic first degree relatives and rheumatoid arthritis patients [64]. In Type 1 diabetic patients responding to this islet autoantigen a significant inverse correlation between T-cell and autoantibody responsiveness was observed. Immunogenetic evaluation showed an association of $H L A-D R 3$ with T-cell responsiveness to ICA69 and absence of ICA69-reactive autoantibodies. The increased T-cell reactivity to ICA69 in the absence of antibody reactivity at onset of Type 1 diabetes was associated with an HLA class II immune response gene, and therefore suggestive of a genetically controlled selective activation of $\mathrm{T}$ helper subsets to a specific autoantigen in humans.

Another study identified naturally processed and presented epitopes of the intracellular domain of the Type 1 diabetes-associated autoantigen IA-2, presented by HLA-DR4 $(D R B 1 * 0401)$ [65]. IA-2ic-derived peptides were eluted from HLA-DR4 that constituted six sets of peptides nested around distinct core regions. Synthetic peptides based on these regions indeed bound to HLA-DR4 and elicited primary T-cell proliferation frequently in HLA-DR4- positive Type 1 diabetic patients, but rarely in non-HLA-DR4 patients, and in none of the tested HLA-DR4 non-diabetic controls. This approach identified an HLA-DR4-specific map of autoantigenic peptides and could lead to a greater understanding of epitope selection which could lead to the generation of sensitive and epitope-specific T-cell assays, provided that HLA gene products are the primary risk factors for Type 1 diabetes. Nonetheless, it is already clear that more than one genetic locus in the $M H C$ region (which is not an HLA gene) contributes to genetic predisposition to the disease [66].

We have previously shown an association of birth weight, infant growth and autoantibodies against IA-2 with increased risk to develop Type 1 diabetes [67]. It is unclear to what extent this predisposition is determined by endogenous (genetic) or exogenous factors. Other studies suggest a relation between vitamin D supplementation in early childhood and risk for Type 1 diabetes $[68,69]$. In this regard, it is of interest that we recently described a genetic polymorphism of the vitamin $\mathrm{D}$ receptor with functional consequences that 
is associated with development of Type 1 diabetes [70]. Intriguingly, this polymorphism was shown to be associated with mRNA and protein levels of the vitamin D receptor, as well as insulin secretory capacity [71]. The active form of vitamin D3 is a potent modulator of differentiation and maturation of dendritic cells, causing redirection in anti-inflammatory dendritic cells that are capable of altering cytokine production profile of proinflammatory Th- 1 autoreactive T-cells [72]. Together, these data provide evidence that vitamin D3 and its receptor are candidate factors associated with risk to develop Type 1 diabetes.

Viral infections have been associated with the development of the neuroendocrine autoimmune diseases Type 1 diabetes and the rare neurological autoimmune disorder stiff-man syndrome (SMS), but the mechanism is unknown. These diseases share glutamic acid decarboxylase GAD65 as a major autoantigen. Antigens of pathogenic microbes that mimic autoantigens are thought to be responsible for the activation of autoreactive T-cells [73]. A role of molecular mimicry between GAD65 and Coxsackie virus protein P2C in the pathogenesis of Type 1 diabetes has been suggested [74]. Co-recognition of GAD65 and its homologous viral peptide of Coxsackie $\mathrm{P} 2 \mathrm{C}$ has been reported on bulk culture level [75, 76]. However, bulk cultures consist of multiple T-cells and an observed cross-reactivity to more than one antigen or peptide might simply reflect T-cell proliferation of several T-cells with different specificity.

Firstly, we isolated and investigated T-cells reactive to GAD65-peptides and homologous peptides of the Coxsackie virus protein $\mathrm{P} 2 \mathrm{C}$ from recent onset Type 1 diabetic patients, and tested their fine specificity and cytokine production profile. None of four T-cell lines reactive to GAD65 peptides (amino acids 247-280) with sequence homology to Coxsackie P2C (amino acids 30-50) cross-reacted to the homologous viral peptide [77]. Two T-cell lines co-recognised a GAD65 peptide and a Coxsackie P2C peptide. However, the antigen-specific T-cell clones from these T-cell lines were reacting either with the GAD65 peptide or the Coxsackie P2C peptide using different restriction elements without cross-reacting to the homologous peptide [77]. Our data shows that homologous peptides previously proposed to serve as targets for cross-reactivity are immunogenic. Yet, T-cell clones did not cross-react with linear sequence homologies, despite strong T-cell responses to individual peptides.

The hypothesis that sequence homology between GAD65 and coxsackie B4 virus could lead to T-cell cross-reactivity has not been supported by functional evidence at clonal level thus far. Hence, an association of coxsackie infection with development of Type 1 diabetes could result from direct lytic activity to beta cells rather than molecular mimicry. We recently reported a case of acute echovirus infection coinciding with clinical onset of juvenile diabetes [78]. Although the viral protein $2 \mathrm{C}$ had a sequence similar to that of GAD65, no cross-reactive T-cell responses were detected. The patient did not develop antibodies to GAD65 either. Lack of evidence for direct cytolytic action or an indirect effect through molecular mimicry with GAD65 in this case raises the possibility of another indirect pathway through which enteroviruses can cause diabetes mellitus. It has also been suggested that coxsackie virus-induced Type 1 diabetes is initiated by bystander damage by autoreactive T-cells after virus infection [79].

Through an entirely different approach, however, T-cell cross-reactivity between GAD65 and human cytomegalovirus major DNA binding protein could be shown [80]. A T-cell clone was isolated from a prediabetic subject 4 years prior to the clinical manifestation of diabetes [81]. This clone was used to define the antigen recognition pattern by screening a random synthetic peptide library dedicated to bind to the relevant HLA restriction element (HLA-DR3 in this case) [82, 83, 84]. A peptide of human cytomegalovirus major DNA-binding protein was identified that stimulated the autoreactive T-cell clone. The hCMV-derived epitope can be naturally processed and recognized by GAD65 reactive T-cells [85].

Clinical onset of Type 1 diabetes and SMS has been reported to be accompanied by acute hCMV infection [86]. Autoimmune beta-cell destruction in pancreatic allografts was associated with recurrent insulitis with a predominant fraction of infiltrating T-cells reactive to hCMV [87]. Also, hCMV infection of mice resulted in the generation of autoantibodies directed to the islets of Langerhans [88]. The mechanism by which hCMV infection contributes to neuroendocrine autoimmunity is unknown. hCMV has been shown to infect beta cells and neuronal tissue as well as peripheral blood mononuclear cells. Alternatively, systemic hCMV infection could lead to the activation of CD4+ T cells by presentation of hCMV peptide in the context of HLA class II. Through molecular mimicry these T-cells could then cross-react with GAD65 of neural cells, leading to autoimmune disease. We thus showed that T-cells reactive to GAD65 crossreact with a peptide of the human cytomegalovirus major DNA-binding protein. This is the first evidence of molecular mimicry in Type 1 diabetes. Human cytomegalovirus could be involved in the loss of tolerance to autoantigen GAD65 by a mechanism of molecular mimicry leading to autoimmunity [85].

\section{Cytokines}

Cytokines and chemokines are essential components in the communication between different components of the immune system, as well as in directing leukocytes to inflammatory lesions. Little is known of which cytokines and chemokines are associated with the patho- 
Table 5. Comparison between autoimmune diabetes in mice and men

\begin{tabular}{|c|c|c|}
\hline & Human & Mice \\
\hline name & Type 1 diabetes mellitus & (exp.) autoimmune diabetes \\
\hline Genetic predisposition & multigenetic trait & multigenetic trait \\
\hline Environmental influence & probable & yes \\
\hline endogenous retrovirus & $?$ & yes \\
\hline incidence & $0.25-0.40 \%$ & $>80 \%$ \\
\hline T-cell driven insulitis & mild & severe \\
\hline periinsulitis & no & yes \\
\hline lymphocyte infiltrates in other tissues & rarely & always \\
\hline disease transmissible with BMT & yes & yes \\
\hline B lymphocytes required & no & yes \\
\hline humoral reactivity to beta cells & GAD65, IA-2, insulin, ICA & insulin \\
\hline
\end{tabular}

genesis of Type 1 diabetes, and to what extent they could reflect attempts of the immune system to counteract immune abnormalities including autoimmunity. There is a common belief that Type 1 diabetes is a Th-1 associated disease, i.e. associated with or accompanied by proinflammatory cytokines and chemokines (Fig. 2). In the past, it has been proposed that Th-2 cells could be beneficial or at least benign in fighting beta-cell destruction, but this hypothesis has been primarily based on animal models. It is clear that in NOD mice the disease process is Th- 1 driven. However, although Th- 2 cells dominate non-destructive periinsulitis in these mice, IL-4 producing Th-cell clones are capable of adoptive transfer of insulitis or even diabetes to non-diabetic immunoincompetent NODscid recipients [89, 90], and incapable to prevent disease [89].

In line with the hypothesis that Type 1 diabetes is Th- 1 dominated is the observation that the majority of autoreactive T-cell clones produce a Th- 1 associated cytokine profile (dominated by interferon-gamma) [91]. Remarkably, the only autoimmune T-cell clone against GAD65 that we isolated from a non-diabetic donor expressed a T-regulatory cytokine profile (IL10 and interferon-gamma) [81]. This pattern was consistent for years until the clinical manifestation of Type 1 diabetes, at which time point the cytokine profile in response to GAD65 had shifted completely to interferon-gamma alone.

Many of the immunointervention strategies that have been tested in vitro in the context of human diabetes have been shown to effectively down-modulate Th-1 associated cytokine profile, often in favour of anti-inflammatory cytokine profiles. These strategies included vitamin D3 modulated dendritic cells [72], protease treatment [57], altered peptide ligands of islet autoantigenic T-cell epitopes [92], glycolipid cocultures [93], and heat-shock protein 60 treatment [94]. Wheth- er or not these strategies will be effective clinically remains to be determined, and depends on the validity of the assumption that the disease results from Th-1, rather than Th-2 associated cytokine deviation. All observations made thus far fit with the working model of the immunopathogenesis of Type 1 diabetes where the interplay between pro- and anti-inflammatory cytokines determines the fate of the beta cells (Fig. 2).

\section{Mouse models for human disease}

The non-obese diabetic (NOD) mouse develops autoimmune mediated disease with features resembling Type 1 diabetes in humans [95]. An important difference is the absence of autoantibodies against islet antigens other than insulin [20], as well as the presence of multiple immune abnormalities including NK cells defects, lymphopenia, cytokine deviations and other autoimmune lesions apparently unrelated to diabetes itself (thyroiditis, gastritis, sialitis) (Table 5). Apart from these evident differences, it has become clear that experimental models in animals cannot be used to determine efficacy of immunointervention studies in humans [95]. In addition, studies on transgenic animals or gene knock-out mice represent case reports that could suffer from cell biological and immunological artefacts unrelated and incompatible with Type 1 diabetes. Finally, care should be taken in comparing and interpreting adoptive transfer studies with Type 1 diabetes in humans, since the mechanism of action shares similarities with graft versus host disease rather than 'spontaneous' autoimmune disease in terms of treatment of recipients, priming and activation status of the lymphocytes and dosage of pathogenic lymphocytes. Nevertheless, despite this having led to misconceptions and erroneous extrapolations and false expec- 


\section{Autoreactivity}
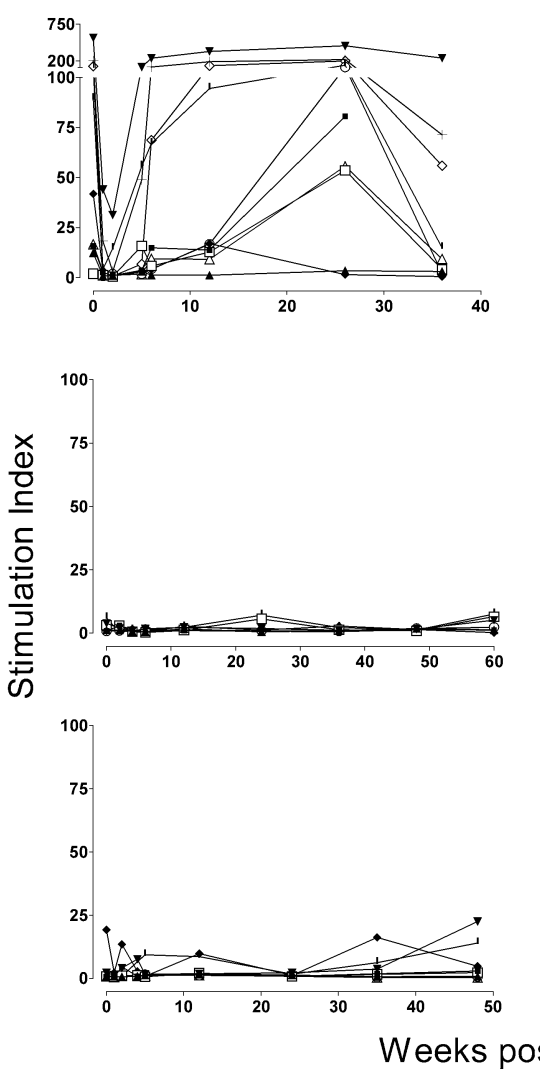

Alloreactivity

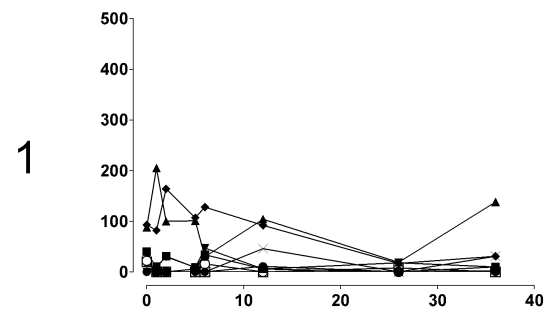

2
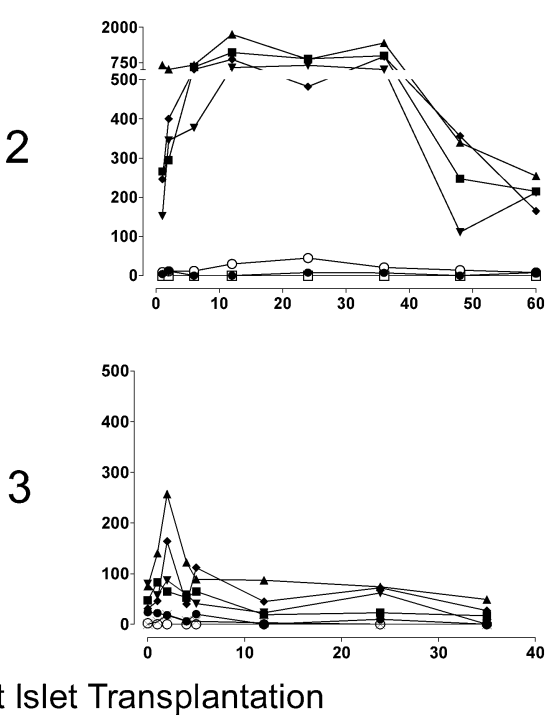

Recurrent autoimmunity; Chronic progressive Cpeptide loss
Fig. 4. The clinical fate of islet allografts transplanted to Type 1 diabetes patients correlates with islet specific T-cell auto- or alloreactivity. Slow progressive loss of islet allograft function is associated with recurrent autoimmunity in the absence of alloreactivity (represented by case 1). Acute loss of islet function is accompanied with immediate induction of islet allograft specific T-cell cytotoxicity (case 2). Persistent C-peptide production is associated with absence of both auto- and alloimmune reactivity (case 3). Modified from Diabetes, Vol. 48, 1999; 484-490

tations with regard to immunotherapy, animal models of autoimmune diabetes have proved to be valuable tools [95]. The genetic predisposition certainly belongs amongst the most striking similarities between mice and men, where the resemblance between the human and murine MHC susceptibility molecules DQ8 and $\mathrm{I}-\mathrm{A}^{\mathrm{g} 7}$ is remarkable [25]. In this regard, it is conceivable that the NOD mouse model could be of help to unravel the functionality of the genetic predisposition to diabetes, despite evident disparities in disease between mice and men.

\section{Immunotherapy}

As argued above, immunotherapies directed against T-cells have been shown to benefit beta-cell preservation $[4,6,10]$. It is conceivable that further under- standing of the role of autoreactive T-cells, as well as elucidating the regulatory processes and identification of regulatory ('suppressive') T-cells involved in immunological control of T-cell autoimmunity, will provide more specific targets from selective immunotherapy. In the context of islet transplantation in Type 1 diabetes patients, T-cell studies have been essential to determine the nature of islet graft failure (Fig. 4) [10]. Slow progressive loss of islet graft function was associated with recurrent (or pre-existent) T-cell autoimmunity, while rapid islet graft destruction was correlated with activation of alloreactive T-cells, with or without T-cell autoreactivity. Successful restoration of beta-cell function and insulin-independency occurred in the absence of both T-cell auto- and alloreactivity. The latter pattern was linked to a history of treatment with anti-lymphocyte globulin (ALG), which implies that irradication of pre-existent T-cell autoimmunity is an important factor to prevent recurrent beta-cell destruction. These studies indicate that immunological monitoring using T-cell assays can help to define optimal immunotherapy, and perhaps customised tapering to reduce therapeutical side effects associated with immunosuppression.

An unexpected, clinically important observation from the in vitro monitoring of T-cell auto- and alloreactivity in Type 1 diabetes patients receiving islet allografts following a previous kidney implantation was the definition of operational tolerance in vivo against 

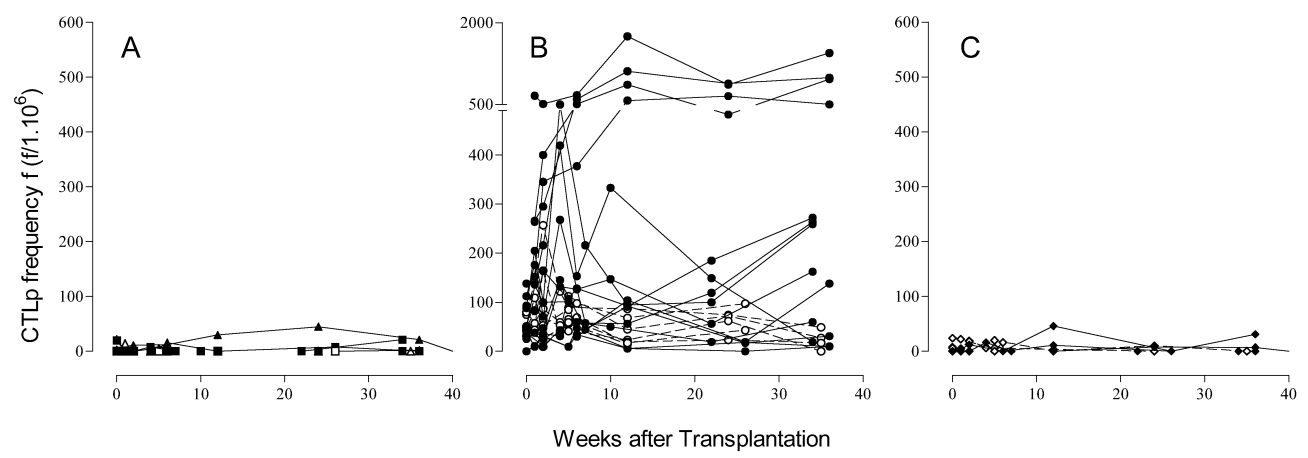

Fig. 5A-C. Kidney allografts induce tolerance in recipients with Type 1 diabetes to islet allografts that share HLA mismatches with the kidney donor. HLA mismatches on islet allografts that are shared with a previously implanted kidney allograft are protected from alloreactive T-cell cytotoxicity, even in case of rapid rejection of the islet allograft. Rejection episodes of the kidney allograft did not occur, despite several cases of acute islet allograft rejection. These results imply that tolerance against HLA mismatched can be induced that is persistent even in case of an in vivo challenge with allografts of different donors that share these mismatches. Indicated are precursor frequencies of alloreactive cytotoxic T-cells of seven transplanted Type 1 diabetes patients against autologous or third party [i.e., different from recipient, kidney donor and islet donor(s)] target cells (A), target cells with alloantigens specifically matched with for islet donors (B) and target cells matched with alloantigens shared with kidney and islet donor(s) (C). Some patients responses to multiple target cells are depicted. Modified from Diabetologia 42:1379-1380, 1999

HLA mismatches shared between the kidney and islet donors (Fig. 5) [96]. Since sequential exposure of the Type 1 diabetes patients with HLA mismatches in both kidney and islet allografts represents an in vivo challenge by the repeated mismatch expressed on the islet allograft, we were concerned that this repeated provocation could jeopardise the kidney allograft that was implanted successfully often years before the islets and sharing the same HLA mismatch. Unexpectedly, we could show that the kidney allograft in fact installs operational tolerance from which subsequent islet allografts that share mismatches with the kidney can actually benefit [96]. Even in the case of an acute rejection of the islet implantation, we could show that the alloreactive cytotoxic T-cells were selectively directed against HLA mismatches exclusively expressed by any of the islet donors, but never against the repeated mismatch also expressed by the kidney graft. Accordingly, rejection episodes of the kidney allografts were never observed after islet allograft rejection. We are currently testing whether, in the case of sequential islet implantation without a previous kidney implantation, islet allograft itself is able to install similar tolerance to mismatches shared between the first and subsequent islet implants. This clinical context provides a rare opportunity to test for tolerance induction against islets.
There is a great demand for immunotherapeutics with limited side effects to provide immunotherapy early in, or even before the initiation of the disease process in both children and adults. The active form of vitamin D3, 1alpha,25-dihydroxyvitamin D3, is a potent immunomodulator known to affect T-cells through targeting antigen-presenting cells such as dendritic cells (DCs). We studied the effects of vitamin D3 and a novel nonhypercalcaemic analogue (TX527) on DC differentiation, maturation, and function with respect to stimulation of a committed human GAD65specific autoreactive T-cell clone (Fig. 2). Continuous addition of vitamin D3 or analogue impaired interleukin-4 and granulocyte/macrophage colony-stimulating factor-driven DC differentiation as well as lipopolysaccharide and interferon-gamma induced maturation into Th1-promoting DC, as characterized by marked changes in DC morphology and abrogation of IL12 p70 release upon CD40 ligation. Addition of vitamin D3 or analogue during maturation did not affect DC morphology but distinctively changed DC cytokine profiles. The potential of treated DCs to alter the response pattern of committed autoreactive T-cells was found to depend on the timing of exposure to vitamin D3 or analogue. Continuously treated DCs inhibited T-cell proliferation and blocked IFN-gamma, IL-10, but not IL-13 production, whereas DCs treated during maturation failed to inhibit T-cell proliferation but affected IL-10 and IFN-gamma production. These findings provided evidence that vitamin D3 is a potent in vitro DC modulator, yielding DCs with the potential to change cytokine responses of committed autoreactive T-cells clones. The latter observation is very relevant, since intervention studies should be capable to deal with pre-existant autoimmunity. Unfortunately, in experimental models of autoimmune diseases it has been shown to be very difficult to intervene after initiation of autoimmunity.

In case of immunotherapeutic strategies aiming at intervention in the pathogenesis of Type 1 diabetes, it is very important to ensure that efforts are made to determine whether the projected immunological effect has been achieved, regardless of the clinical efficacy of the potential treatment. This could firstly provide the proof of principle that a given therapy leads to the wanted immunological change, and secondly provides 
the possibility to improve the efficacy of this treatment. Without information on immunological efficacy of a given immunotherapy, clinical trials with potential success that do not lead to clinical benefit because they did not achieve the aimed immunolocal effect for practical reasons (such as wrong dosage, wrong regimen, inefficient frequency or duration of treatment, sub optimal adjuvant, inappropriate therapeutic window, or sub maximal immune deviation), rather than theoretic flaws, could be abandoned prematurely. For instance, provided that prophylactic insulin therapy as tested in the Diabetes Prevention Trial-1 in NorthAmerica has an immunological component, in addition to a metabolic effect, there is no immunological evidence that the approach chosen in the clinical trial was appropriate $[97,98,99,100,101]$. Alterations in autoimmune T-cell responses to insulin can be detected following initiation of insulin therapy at diagnosis of Type 1 diabetes that suggest suppression of T-cell reactivity or induction of tolerance to insulin [22], indicating a potential benificial immunological effect of insulin therapy. Unfortunately, there are too few data on T-cell autoreactivity collected in the clinical trial to allow determining whether the dosage regimen was appropriate to generate this immunological effect. The latter could be one of the reasons why insulin prophylaxis did not provide any clinical benefit as yet. Similarly, the results of islet transplantation in Type 1 diabetic patients were very disappointing for many years, but studies to determine whether auto- and alloreactivity were dealt with sufficiently in these situations were lacking. Careful and extensive immunological studies have now provided compelling evidence that the fate of the islet allograft is determined by effective immunotherapy directed against T-cells $[10$, 102]. Such studies will improve the success of clinical islet transplantation in the future by improved immunotherapy [103].

We recently finished an extensive immunological monitoring involving over 32000 elispot assays of a double-blinded placebo controlled trial where a synthetic peptide of heat-shock protein 60 was tested for its capacity to induce an anti-inflammatory cytokine response that should allow one to determine whether the immunization strategy was sufficient, and to assess whether the observed changes in autoimmunity are associated with any clinical benefit on preservation of beta-cell function. At the same time, we are involved in the immunological monitoring of aglycosylated humanized anti-CD3 therapy at clinical manifestation of Type 1 diabetes, in a trial coordinated by another group $[104,105,106]$ that could act in a similar way to an anti-CD3 therapy recently reported [6].

With the development of new technologies, such as cytokine analysis using enzyme-linked immunosorbant spot assays (ELISPOT) and HLA tetramers that allow quick detection of peptide specific T-cells in the context of their restriction element, the stage has been set to improve the qualitative and quantitative detection of autoreactive T-cells in endocrine autoimmunity. In combination with functional studies as described here, such studies will help to understand the cause of Type 1 diabetes, and provide therapy of this endocrine autoimmune disease.

\section{Conclusion}

We have come a long way in the last decade in understanding the pathogenesis of Type 1 diabetes and the contribution of T-cells in the disease process. The challenge for the future is to determine which factors contribute to the loss of tolerance to beta-cell antigens, and to define what measures T-cells can provide to suppress autoreactivity, since it is becoming increasingly evident that T-cells provide a two-edged sword: some T-cells may be pathogenic, but others can regulate the disease process and thus form new targets for immunointervention. However, immunotherapies directed against T-cells are already in use, and prove successful to preserve beta cells. The quest will be to define milder therapies that act selectively on autoreactive T-cells, to allow broader use with less side effects.

Acknowledgements. I am eternally grateful for the continuous support, constructive opposition and mind-shaping by R. de Vries. He ensured that I kept focussed on human diabetes. I also wish to share the honour associated with the Minkowski Prize with my past, present and future collaborators and friends M. Giphart, J. Bruining, G. Duinkerken, B. Koeleman, N. Schloot, A. van Halteren, P. Hanifi Moghaddam, A. van der Slik, P. Eerligh, F. Claas, I. Stobbe ${ }^{\dagger}$, P. van de Linde, C. van Kampen, H. Romijn, A. Perreira, J. Wouter Drijfhout, B. Hiemstra, A. Kallan, W. Verduijn, L. Schreuder, S. Willemen, O. Tysma, M. Batstra, H.-J. Aanstoot, G. Vreugdenhil, J. Galama, J. Hutton, K. Buschard, S. Martin, H. Kolb, T. Mandrup Poulsen, G. Eisenbarth, M. Peakman, T. Tree, D. Pipeleers, B. Keymeulen, C. Mathieu, Å. Lernmark, J. Palmer, H. Reijonen, G. Nepom, F. Bottazzo, K. Rønningen, M. Christie, M. Atkinson, M. Honeyman, S. Baekkeskov, E. Bonifacio, F. Dotta, U. DiMario, P. Marchetti, E. Bosi, I. Cohen, I. Durinovic Bello, M. Knip, E. Gale, H. Akerblom and P. Hanifi Moghaddam . The studies in Leiden have been supported by the Diabetes Fonds Nederland, the National Research Council, the European Community, the Juvenile Diabetes Research Foundation, the Royal Academy of Arts and Sciences, Macropa, and the Child Health and Wellbeing Fund. I dedicate my Minkowski Prize to Luna Maria Roep and Gaby Duinkerken-Roep.

\section{References}

1. Kolb H, Kolb-Bachofen V, Roep BO (1995) Autoimmune versus inflammatory type I diabetes: a controversy? Immunol Today 16:170-172

2. Gepts W (1965) Pathologic anatomy of the pancreas in juvenile diabetes mellitus. Diabetes 14:619-663 
3. Bottazzo GF, Dean BM, McNally JM, MacKay EH, Swift PGF, Gamble DR (1985) In situ characterization of autoimmune phenomena and expression of HLA class II molecules in the pancreas in diabetic insulitis. $\mathrm{N}$ Engl $\mathrm{J}$ Med 313:353-360

4. Bougneres PF, Carel JC, Castano L et al. (1988) Factors associated with early remission of type I diabetes in children treated with cyclosporine. N Engl J Med 318:663-670

5. Mandrup-Poulsen T, Molvig J, Andersen HU, Helqvist S, Spinas GA, Munck M (1990) Lack of predictive value of islet cell antibodies, insulin antibodies, and HLA-DR phenotype for remission in cyclosporin- treated IDDM patients. The Canadian-European Randomized Control Trial Group. Diabetes 39:204-210

6. Herold KC, Hagopian W, Auger JA et al. (2002) AntiCD3 monoclonal antibody in new-onset type 1 diabetes. N Engl J Med 346:1692-1698

7. Sibley R, Sutherland DER, Goetz F, Michael AF (1985) Recurrent diabetes mellitus in the pancreas iso- and allograft. A light and electron microscopic and immunohistochemical analysis of four cases. Lab Invest 53:132-144

8. Lampeter EF, Homberg M, Quabeck K et al. (1993) Transfer of insulin-dependent diabetes between HLAidentical siblings by bone marrow transplantation. Lancet 341:1243-1244

9. Roep BO, Arden SD, De Vries RRP, Hutton JC (1990) T-cell clones from a type-1 diabetes patient respond to insulin secretory granule proteins. Nature 345:632-634

10. Roep BO, Stobbe I, Duinkerken G et al. (1999) Auto- and alloimmune reactivity to human islet allografts transplanted to insulin-dependent diabetes mellitus patients. Diabetes 48:484-490

11. Roep BO (1996) T-cell responses to autoantigens in IDDM. The search for the Holy Grail. Diabetes 45:1147-1156

12. Bottazzo GF, Florin-Christensen A, Doniach D (1974) Islet cell antibodies in diabetes mellitus with autoimmune polyendocrine deficiencies. Lancet ii: 1279-1282

13. Palmer JP, Asplin CM, Clemons P et al. (1983) Insulin antibodies in insulin-dependent diabetes before insulin treatment. Science 222:1337-1339

14. Aanstoot HJ, Kang SM, Kim J et al. (1996) Identification and characterization of glima 38 , a glycosylated islet cell membrane antigen, which together with GAD65 and IA2 marks the early phases of autoimmune responses in type 1 diabetes. J Clin Invest 97:2772-2783

15. Baekkeskov S, Aanstoot HJ, Christgau S et al. (1990) Identification of the $64 \mathrm{~K}$ autoantigen in insulin-dependent diabetes as the GABA-synthesizing enzyme glutamic acid decarboxylase. Nature 347:151-156

16. Atkinson MA, Kaufman DL, Campbell L et al. (1992) Response of peripheral-blood mononuclear cells to glutamate decarboxylase in insulin-dependent diabetes. Lancet 339:458-459

17. Roep BO, Kallan AA, Duinkerken G et al. (1995) T-cell reactivity to beta-cell membrane antigens associated with beta- cell destruction in IDDM. Diabetes 44:278-283

18. Brooks-Worrell BM, Starkebaum GA, Greenbaum C, Palmer JP (1996) Peripheral blood mononuclear cells of insulin-dependent diabetic patients respond to multiple islet cell proteins. J Immunol 157:5668-5674

19. Pugliese A, Zeller M, Fernandez A Jr et al. (1997) The insulin gene is transcribed in the human thymus and transcription levels correlated with allelic variation at the INS VNTR-IDDM2 susceptibility locus for type 1 diabetes. Nat Genet 15:293-297

20. Bonifacio E, Atkinson M, Eisenbarth G et al. (2001) International Workshop on Lessons From Animal Models for
Human Type 1 Diabetes: identification of insulin but not glutamic acid decarboxylase or IA-2 as specific autoantigens of humoral autoimmunity in nonobese diabetic mice. Diabetes 50:2451-2458

21. Harrison LC, Honeyman MC, De Aizpurua HJ et al. (1993) Inverse relation between humoral and cellular immunity to glutamic acid decarboxylase in subjects at risk of insulin-dependent diabetes. Lancet 341:1365-1369

22. Schloot NC, Roep BO, Wegmann D et al. (1997) Altered immune response to insulin in newly diagnosed versus insulin treated diabetic patients and healthy control subjects. Diabetologia 40:564-572

23. Reijonen H, Daniels TL, Lernmark A, Nepom GT (2000) GAD65-specific autoantibodies enhance the presentation of an immunodominant T-cell epitope from GAD65. Diabetes 49:1621-1626

24. Martin S, Wolf-Eichbaum D, Duinkerken G et al. (2001) Development of type 1 diabetes despite severe hereditary B-lymphocyte deficiency. N Engl J Med 345:1036-1040

25. McDevitt H (2001) Closing in on type 1 diabetes. N Engl J Med 345:1060-1061

26. Ludvigsson J, Heding L, Lieden G, Marner B, Lernmark A (1983) Plasmapheresis in the initial treatment of insulindependent diabetes mellitus in children. BMJ 286:176-178

27. Wilson SB, Kent SC, Patton KT et al. (1998) Extreme Th1 bias of invariant Valpha24JalphaQ $\mathrm{T}$ cells in type 1 diabetes. Nature 391:177-181

28. Jansen A, van HM, Drexhage HA (1995) Defective maturation and function of antigen-presenting cells in type 1 diabetes. Lancet 345:491-492

29. Peakman M, Alviggi L, Hussain MJ et al. (1994) Increased expression of T-Cell markers of immunological memory associated with protection from type I diabetes a study of identical twins. Diabetes 43:712-717

30. Peakman M, Leslie RDG, Vergani D (1993) Immunological studies on Type-1 diabetes in identical twins. Arch Dis Child 69:97-99

31. Peakman M, Mahalingam M, Leslie RD, Vergani D (1994) Co-expression of CD45RA (naive) and CD45R0 (memory) T-cell markers. Lancet 343:424

32. Douglas Petersen L, Duinkerken G, Bruining GJ, van Lier R, De Vries RRP, Roep BO (1996) Increased numbers of in vivo activated T-cells in patients with recent onset diabetes mellitus. J Autoimmun 9:731-737

33. al-Sakkaf L, Pozzilli P, Bingley PJ et al. (1992) Early T-cell defects in pre-type-1 diabetes. Acta Diabetol 28:189-192

34. al-Sakkaf L, Pozzilli P, Tarn AC, Schwarz G, Gale EA, Bottazzo GF (1989) Persistent reduction of CD4/CD8 lymphocyte ratio and cell activation before the onset of type 1 (insulin-dependent) diabetes. Diabetologia 32:322-325

35. Faustman D, Eisenbarth G, Daley J, Breitmeyer J (1989) Abnormal T-lymphocyte subsets in type I diabetes. Diabetes 38:1462-1468

36. Faustman DL (1993) Occult CD45 T cell developmental defect in type 1 diabetes. Diabete Metab 19:446-457

37. Douglas Petersen L, Van der Keur M, De Vries RRP, Roep BO (1999) Autoreactive and immunoregulatory T-cell subsets in insulin dependent diabetes mellitus. Diabetologia 42:443-449

38. Worsaae A, Hejnaes K, Moody A et al. (1995) T cell proliferative responses to glutamic acid decarboxylase-65 in IDDM are negatively associated with HLA DR3/4. Autoimmunity 22:183-189

39. Roep BO, Atkinson MA, van Endert PM, Gottlieb PA, Wilson SB, Sachs JA (1999) Autoreactive T cell responses in insulin-dependent (Type 1) diabetes mellitus. 
Report of the first international workshop for standardization of T cell assays. J Autoimmun 13:267-282

40. Honeyman MC, Cram DS, Harrison LC (1993) Glutamic acid decarboxylase 67-reactive T cells: a marker of insulin-dependent diabetes. J Exp Med 177:535-540

41. Honeyman MC, Stone N, de AH, Rowley MJ, Harrison LC (1997) High T cell responses to the glutamic acid decarboxylase (GAD) isoform 67 reflect a hyperimmune state that precedes the onset of insulin-dependent diabetes. J Autoimmun 10:165-173

42. Powrie F, Leach MW, Mauze S, Menon S, Caddle LB, Coffman RL (1994) Inhibition of Th1 responses prevents inflammatory bowel disease in scid mice reconstituted with CD45RB(hi) CD4(+) T cells. Immunity 1:553-562

43. Groux H, O'Garra A, Bigler M et al. (1997) A CD4+ Tcell subset inhibits antigen-specific T-cell responses and prevents colitis. Nature 389:737-742

44. Suri-Payer E, Amar AZ, Thornton AM, Shevach EM (1998) CD4+CD25+ T cells inhibit both the induction and effector function of autoreactive $\mathrm{T}$ cells and represent a unique lineage of immunoregulatory cells. J Immunol 160:1212-1218

45. Baecher-Allan C, Viglietta V, Hafler DA (2002) Inhibition of human CD4(+)CD25(+high) regulatory T cell function. J Immunol 169:6210-6217

46. Baecher-Allan C, Brown JA, Freeman GJ, Hafler DA (2002) CD4+CD25high regulatory cells in human peripheral blood. J Immunol 167:1245-1253

47. Levings MK, Bacchetta R, Schulz U, Roncarolo MG (2002) The role of IL-10 and tgf-Beta in the differentiation and effector function of $\mathrm{T}$ regulatory cells. Int Arch Allergy Immunol 129:263-276

48. Peakman M, Tree TI, Endl J, van Endert P, Atkinson MA, Roep BO (2001) Characterization of preparations of GAD65, proinsulin, and the islet tyrosine phosphatase IA-2 for use in detection of autoreactive T-cells in type 1 diabetes: report of phase II of the Second International Immunology of Diabetes Society Workshop for Standardization of T-cell assays in type 1 diabetes. Diabetes 50:1749-1754

49. Roep BO (1999) Standardization of T-cell assays in Type I diabetes. Immunology of diabetes society T-cell committee. Diabetologia 42:636-637

50. Bingley PJ, Bonifacio E, Ziegler AG, Schatz DA, Atkinson MA, Eisenbarth GS (2001) Proposed guidelines on screening for risk of type 1 diabetes. Diabetes Care 24:398.

51. Atkinson MA, Honeyman MC, Peakman M, Roep BO (2000) T-cell markers in type 1 diabetes: progress, prospects and realistic expectations. Diabetologia 43:819-820

52. Abulafia-Lapid R, Elias D, Raz I, Keren-Zur Y, Atlan H, Cohen IR (1999) $\mathrm{T}$ cell proliferative responses of type 1 diabetes patients and healthy individuals to human hsp60 and its peptides. J Autoimmun 12:121-129

53. Neophytou PI, Roep BO, Arden SD et al. (1996) T-cell epitope analysis using subtracted expression libraries (TEASEL): application to a $38-\mathrm{kDA}$ autoantigen recognized by $\mathrm{T}$ cells from an insulin-dependent diabetic patient. Proc Natl Acad Sci USA 93:2014-2018

54. Arden SD, Roep BO, Neophytou PI et al. (1996) Imogen 38: a novel $38-\mathrm{kD}$ islet mitochondrial autoantigen recognized by $\mathrm{T}$ cells from a newly diagnosed type 1 diabetic patient. J Clin Invest 97:551-561

55. Roep BO, Heidenthal E, de Vries RR, Kolb H, Martin S (1994) Soluble forms of intercellular adhesion molecule-1 in insulin-dependent diabetes mellitus. Lancet 343:1590-1593

56. Martin S, Rieckmann P, Melchers I et al. (1995) Circulating forms of ICAM-3 (cICAM-3). Elevated levels in auto- immune diseases and lack of association with cICAM-1. J Immunol 154:1951-1955

57. Roep BO, van den Engel NK, van Halteren AG, Duinkerken G, Martin S (2002) Modulation of autoimmunity to beta-cell antigens by proteases. Diabetologia 45 : 686-692

58. Geluk A, Van Meijgaarden KE, Roep BO, Ottenhoff TH (1998) Altered peptide ligands of islet autoantigen Imogen 38 inhibit antigen specific $\mathrm{T}$ cell reactivity in human type-1 diabetes. J Autoimmun 11:353-361

59. Buschard K, Schloot NC, Kaas A et al. (1999) Inhibition of insulin-specific autoreactive T-cells by sulphatide which is variably expressed in beta cells. Diabetologia 42:1212-1218

60. Greening J, Tree TIM, Kotowicz KT et al. (2003) Processing and presentation of the islet autoantigen glutamic acid decarboxylase by vascular endothelial cells promotes transmigration of autoreactive T cells. Diabetes 52:717-725

61. Schipper RF, Koeleman BP, Bruining GJ et al. (2001) HLA class II associations with Type 1 diabetes mellitus: a multivariate approach. Tissue Antigens 57:144-150

62. Geluk A, van Meijgaarden KE, Schloot NC, Drijfhout JW, Ottenhoff TH, Roep BO (1998) HLA-DR binding analysis of peptides from islet antigens in IDDM. Diabetes 47: 1594-1601

63. Petrovsky N, Harrison LC (1995) HLA-matched control subjects are essential in studies of susceptibility to IDDM. Diabetologia 38:125-126

64. Roep BO, Duinkerken G, Schreuder GM, Kolb H, de Vries RR, Martin S (1996) HLA-associated inverse correlation between $\mathrm{T}$ cell and antibody responsiveness to islet autoantigen in recent-onset insulin-dependent diabetes mellitus. Eur J Immunol 26:1285-1289

65. Peakman M, Stevens EJ, Lohmann T et al. (1999) Naturally processed and presented epitopes of the islet cell autoantigen IA-2 eluted from HLA-DR4. J Clin Invest 104:1449-1457

66. Hanifi Moghaddam P, de Knijff P, Roep BO et al. (1998) Genetic structure of IDDM1: two separate regions in the major histocompatibility complex contribute to susceptibility or protection. Diabetes 47:263-269

67. Bruining GJ (2000) Association between infant growth before onset of juvenile type-1 diabetes and autoantibodies to IA-2. Netherlands Kolibrie study group of childhood diabetes. Lancet 356:655-656

68. The EURODIAB Substudy 2 Study Group (1999) Vitamin D supplement in early childhood and risk for Type I (insulin- dependent) diabetes mellitus. Diabetologia 42:51-54

69. Hypponen E, Laara E, Reunanen A, Jarvelin MR, Virtanen SM (2001) Intake of vitamin D and risk of type 1 diabetes: a birth-cohort study. Lancet 358:1500-1503

70. Koeleman BP, Valdigem G, Eerligh P, Giphart MJ, Roep BO (2002) Seasonality of birth in patients with type 1 diabetes. Lancet 359:1246-1247

71. Ogunkolade BW, Boucher BJ, Prahl JM et al. (2002) Vitamin D receptor (VDR) mRNA and VDR protein levels in relation to vitamin D status, insulin secretory capacity, and VDR genotype in Bangladeshi Asians. Diabetes 51:2294-2300

72. Van Halteren AG, van Etten E, de Jong EC, Bouillon R, Roep BO, Mathieu C (2002) Redirection of human autoreactive T-cells upon interaction with dendritic cells modulated by TX527, an analog of 1,25 dihydroxyvitamin D(3). Diabetes 51:2119-2125

73. Oldstone MBA (1998) Molecular mimicry and immunemediated diseases. FASEB J 12:1255-1265

74. Tian J, Lehmann PV, Kaufman DL (1994) T cell cross-reactivity between coxsackievirus and glutamate decarbox- 
ylase is associated with a murine diabetes susceptibility allele. J Exp Med 180:1979-1984

75. Atkinson MA, Bowman MA, Campbell L, Darrow BL, Kaufman DL, Maclaren NK (1994) Cellular immunity to a determinant common to glutamate decarboxylase and Coxsackie virus in insulin-dependent diabetes. J Clin Invest 94:2125-2129

76. Schloot NC, Roep BO, Wegmann DR, Yu L, Wang T, Eisenbarth GS (1997) T-cell reactivity of GAD65 peptide sequences shared with coxsackie virus protein in recent onset IDDM, post onset IDDM patients and control subjects. Diabetologia 40:332-338

77. Schloot NC, Willemen SJM, Duinkerken G, Drijfhout JW, De Vries RRP, Roep BO (2001) Molecular mimicry in type 1 diabetes revisited: T-cell clones to GAD65 peptides with sequence homology to coxsackie and proinsulin peptides do not crossreact with homologous counterpart. Hum Immunol 62:299-309

78. Vreugdenhil GR, Schloot NC, Hoorens A et al. (2000) Acute onset of type I diabetes mellitus after severe echovirus 9 infection: putative pathogenic pathways. Clin Infect Dis 31:1025-1031

79. Horwitz MS, Bradley LM, Harbertson J, Krahl T, Lee J, Sarvetnick N (1998) Diabetes induced by Coxsackie virus: initiation by bystander damage and not molecular mimicry. Nat Med 4:781-785

80. Hiemstra HS, Schloot NC, Van Veelen PA et al. (2001) Cytomegalovirus in autoimmunity: $\mathrm{T}$ cell crossreactivity to viral antigen and autoantigen glutamic acid decarboxylase. Proc Natl Acad Sci USA 98:3988-3991

81. Schloot NC, Batstra M, Duinkerken G et al. (1999) GAD65 reactive autoreactive T-cells in a non-diabetic Stiff-man syndrome patient. J Autoimmun 12:289-296

82. Hiemstra HS, Van Veelen PA, Schloot NC et al. (1998) Definition of natural $\mathrm{T}$ cell antigens with mimicry epitopes obtained from dedicated synthetic peptide libraries. J Immunol 161:4078-4082

83. Hiemstra HS, Drijfhout JW, Roep BO (2000) Antigen arrays in T cell immunology. Curr Opin Immunol 12:80-84

84. Hiemstra HS, Van Veelen PA, Willemen SJ et al. (1999) Quantitative determination of TCR cross-reactivity using peptide libraries and protein databases. Eur J Immunol 29:2385-2391

85. Hiemstra HS, Schloot NC, Van Veelen PA et al. (2001) Cytomegalovirus in autoimmunity: $\mathrm{T}$ cell crossreactivity to viral antigen and autoantigen glutamic acid decarboxylase. Proc Natl Acad Sci USA 98:3988-3991

86. Pak CY, Eun HM, McArthur RG, Yoon JW (1988) Association of cytomegalovirus infection with autoimmune type 1 diabetes. Lancet ii:1-4

87. Santamaria P, Nakhleh RE, Sutherland DE, Barbosa JJ (1992) Characterization of T lymphocytes infiltrating human pancreas allograft affected by isletitis and recurrent diabetes. Diabetes 41:53-61

88. Pak CY, Cha CY, Rajotte RV, McArthur RG, Yoon JW (1990) Human pancreatic islet cell specific 38 kilodalton autoantigen identified by cytomegalovirus-induced monoclonal islet cell autoantibody. Diabetologia 33: 569-572

89. Katz JD, Benoist C, Mathis D (1995) T helper cell subsets in insulin-dependent diabetes. Science 268:1185-1188

90. Daniel D, Gill RG, Schloot N, Wegmann D (1995) Epitope specificity, cytokine production profile and diabetogenic activity of insulin-specific $\mathrm{T}$ cell clones isolated from NOD mice. Eur J Immunol 25:1056-1062

91. Kallan AA, Duinkerken G, de Jong R et al. (1997) Th1-like cytokine production profile and individual spe- cific alterations in TCRBV-gene usage of T-cells from newly diagnosed type 1 diabetes patients after stimulation with $\beta$-cell autoantigens. J Autoimmun 10:589-598

92. Geluk A, Van Meijgaarden KE, Roep BO, Ottenhoff TH (1998) Altered peptide ligands of islet autoantigen Imogen-38 inhibit antigen specific T-cell reactivity in human type-1 diabetes. J Autoimmun 11:353-361

93. Buschard K, Schloot NC, Kaas A et al. (1999) Inhibition of insulin-specific autoreactive T-cells by sulphatide which is variably expressed in beta cells. Diabetologia 42:1212-1218

94. Raz I, Elias D, Avron A, Tamir M, Metzger M, Cohen IR (2001) Beta-cell function in new-onset type 1 diabetes and immunomodulation with a heat-shock protein peptide (DiaPep277): a randomised, double-blind, phase II trial. Lancet 358:1749-1753

95. Atkinson MA, Leiter EH (1999) The NOD mouse model of type 1 diabetes: as good as it gets? Nat Med 5:601-604

96. Stobbe I, Duinkerken G, van Rood JJ et al. (1999) Tolerance to kidney allograft transplanted into Type I diabetic patients persists after in vivo challenge with pancreatic islet allografts that express repeated mismatches. Diabetologia 42:1379-1380

97. Aaen K, Rygaard J, Josefsen K et al. (1990) Dependence of Antigen Expression on Functional State of $\beta$-Cells. Diabetes 39:697-701

98. Schloot N, Eisenbarth GS (1995) Isohormonal therapy of endocrine autoimmunity. Immunology Today 16:289-294

99. Keller RJ, Eisenbarth GS, Jackson RA (1993) Insulin prophylaxis in individuals at high risk of type I diabetes. Lancet 341:927-928

100. Diabetes Prevention Trial - Type 1 Diabetes Study Group (2002) Effects of insulin in relatives of patients with type 1 diabetes mellitus. N Engl J Med 346:1685-1691

101. Gale EAM (2002) Can we change the course of beta-cell destruction in type 1 diabetes? N Engl J Med 346:1740-1742

102. Bosi E, Braghi S, Maffi P et al. (2001) Autoantibody response to islet transplantation in type 1 diabetes. Diabetes 50:2464-2471

103. Shapiro AM, Lakey JR, Ryan EA et al. (2000) Islet transplantation in seven patients with type 1 diabetes mellitus using a glucocorticoid-free immunosuppressive regimen. N Engl J Med 343:230-238

104. Chatenoud L (2001) Restoration of self-tolerance is a feasible approach to control ongoing beta-cell specific autoreactivity: its relevance for treatment in established diabetes and islet transplantation. Diabetologia 44:521-536

105. Chatenoud L, Primo J, Bach JF (1997) CD3 antibody-induced dominant self tolerance in overtly diabetic NOD mice. J Immunol 158:2947-2954

106. Friend PJ, Hale G, Chatenoud L et al. (1999) Phase I study of an engineered aglycosylated humanized CD3 antibody in renal transplant rejection. Transplantation 68:1632-1637

107. Santamaria P, Nakhleh RE, Sutherland DE, Barbosa JJ (1992) Characterization of T lymphocytes infiltrating human pancreas allograft affected by isletitis and recurrent diabetes. Diabetes 41:53-61

108. Hanafusa T, Miyazaki A, Miyagawa J (1990) Examination of islets in the pancreas biopsy specimens from newly diagnosed type 1 (insulin-dependent) diabetic patients. Diabetologia 33:105-111

109. Imagawa A, Hanafusa T, Itoh $\mathrm{N}$ et al. (1996) Islet-infiltrating $\mathrm{t}$ lymphocytes in insulin-dependent diabetic patients express CD80 (B7-1) and CD86 (B7-2). J Autoimmun 9:391-396

110. Somoza N, Vargas F, Rouramir C et al. (1994) Pancreas in recent onset insulin-dependent diabetes mellitus - changes 
in HLA, adhesion molecules and autoantigens, restricted $\mathrm{T}$ cell receptor $\mathrm{V}$ beta usage, and cytokine profile. $\mathrm{J}$ Immunol 153:1360-1377

111. Dupre J, Stiller CR (1988) Effects of immunosuppression with cyclosporine on beta cell function and clinical remission in very early overt type I diabetes. Adv Exp Med Biol 246:347-355

112. Bougneres PF, Landais P, Boisson C et al. (1990) Limited duration of remission of insulin dependency in children with recent overt type I diabetes treated with low-dose cyclosporin. Diabetes 39:1264-1272

113. Silverstein J, Maclaren N, Riley W, Spillar R, Radjenovic D, Johnson S (1988) Immunosuppression with azathioprine and prednisone in recent onset insulin-dependent diabetes mellitus. N Engl J Med 319:599-604

114. Roep BO, Kallan AA, Hazenbos WL et al. (1991) T-cell reactivity to $38 \mathrm{kD}$ insulin-secretory-granule protein in patients with recent-onset type 1 diabetes. Lancet 337: 1439-1441

115. Ellis T, Schatz D, Ottendorfer E, Wasserfall C, Maclaren N, Atkinson M (1997) Cellular immune reactivities against proinsulin in insulin dependent diabetes.Diabetes 40: [Suppl.1] (Abstract)

116. Hawkes CJ, Schloot NC, Marks J et al. (2000) T-cell lines reactive to an immunodominant epitope of the tyrosine phosphatase-like autoantigen IA-2 in type 1 diabetes. Diabetes 49:356-366

117. Harrison LC, Chu SX, DeAizpurua HJ, Graham M, Honeyman MC, Colman PG (1992) Islet-reactive T cells are a marker of preclinical insulin-dependent diabetes. J Clin Invest 89:1161-1165

118. Peakman M, Warnock T, Vats A et al. (1994) Lymphocyte subset abnormalities, autoantibodies and their relationship with HLA DR types in children with type 1 (insulindependent) diabetes and their first degree relatives. Diabetologia $37: 155-165$

119. Durinovic-Bello I (1998) Autoimmune diabetes: the role of T cells, MHC molecules and autoantigens. Autoimmunity 27:159-177
120. Thorsby E, Lundin KE, Ronningen KS, Sollid LM, Vartdal F (1989) Molecular basis and functional importance of some disease-associated HLA polymorphisms. Tissue Antigens 34:39-49

121. Zhang J, Markovic-Plese S, Lacet B, Raus J, Weiner HL, Hafler DA (1994) Increased frequency of interleukin 2-responsive $\mathrm{T}$ cells specific for myelin basic protein in peripheral blood and cerebrospinal fluid of patients with multiple sclerosis. J Exp Med 179:973-984

122. Reijonen H, Novak EJ, Kochik S et al. (2002) Detection of GAD65-specific T-cells by major histocompatibility complex class II tetramers in type 1 diabetic patients and at-risk subjects. Diabetes 51:1375-1382

123. Peterson LD, van der KM, de Vries RR, Roep BO (1999) Autoreactive and immunoregulatory T-cell subsets in insulin-dependent diabetes mellitus. Diabetologia 42:443-449

124. Roep BO, Duinkerken G, Schreuder GM, Kolb H, de Vries RR, Martin S (1996) HLA-associated inverse correlation between $\mathrm{T}$ cell and antibody responsiveness to islet autoantigen in recent-onset insulin-dependent diabetes mellitus. Eur J Immunol 26:1285-1289

125. Ellis TM, Darrow B, Campbell L, Atkinson MA (1995) Inverse relationship between humoral and cellular immune responses to glutamate decarboxylase 65 (GAD) and insulin in IDD. Diabetes 44S:A52

126. Ellis TM, Schatz DA, Ottendorfer EW et al. (1998) The relationship between humoral and cellular immunity to IA-2 in IDDM. Diabetes 47:566-569

127. Stobbe I, Duinkerken G, Van Rood JJ et al. (1999) Tolerance to kidney allograft transplanted into Type I diabetic patients persists after in vivo challenge with pancreatic islet allografts that express repeated mismatches. Diabetologia 42:1379-1380

128. Alleva DG, Crowe PD, Jin L et al. (2001) A disease-associated cellular immune response in type 1 diabetics to an immunodominant epitope of insulin. J Clin Invest 107: $173-180$ 